\title{
NGO が取り組むバングラデシュの地下水ヒ素污染問題
}

\author{
末永和幸*・応用地質研究会ヒ素污染研究グループ**
}

\section{Research Activities of NGO to Tackle Arsenic Problem in Bangladesh}

Kazuyuki SUENAGA* and Research Group for Applied Geology (RGAG)**

\begin{abstract}
The groundwater contamination by Arsenic (As) becomes a serious problem for human health in Bangladesh; having more than $0.05 \mathrm{mg} / \mathrm{L}$ in As concentration in widespread areas. The Research Group for Applied Geology (RGAG) carried out hydrogeological investigations at Samta village in western Bangladesh together with the Asia Arsenic Network (AAN), Bangladeshi scientists and the villagers.

The As concentration is higher in the first aquifer where most domestic wells tap, and the As content is higher in the upper muddy layer underlain by the first aquifer in Samta. The groundwater level steeply drops down in dry season when groundwater is extensively used for irrigation. It is possible that the As contamination is accelerated by the heavy groundwater pumpage.

It is necessary to make detailed investigations in the As affected areas for establishment of groundwater management system in Bangladesh. Interdisciplinary approaches with international collaboration are also needed to combat arsenic problems to be occurred in different places in the world.
\end{abstract}

Key Words: arsenic, groundwater contamination, Ganges delta, NGO, international cooperation, Bangladesh 
バングラデシュでは国土の大半の地域で、地下水中ヒ素濃度が $0.05 \mathrm{mg} / \mathrm{L}$ を越えるとい う深刻な事態が発生している。応用地質研究会は、AAN や地元研究者・住民らと協力し て、水文地質学的調査を実施してきた。

調査の結果、地下水中七素濃度は飲料水利用の多い帯水層で高く、地層中七素含有量は 主帯水層上位の泥質層で高いことが確認された。また、年間地下水位変動は農業用地下水 利用時期に急激に低下しており、農業用地下水の過剩揚水が七素污染の進行を促進してい る可能性がある。さらなる詳細な調査の実施とともに、地下水利用の管理体制を国家的規 模で確立する必要がある。今後、世界各地で普遍的に起こりうる広域的地下水污染問題に 対し、専門分野の枠を越えた議論が展開されることが期待される。

キーワード：ヒ素、地下水污染、ガンジスデル夕、非政府組織、国際協力、バングラデシュ

\section{1.はじめに}

現在、アジア地域を中心として地下水ヒ素污染 問題が顕在化し、多くの住民に健康被害が発生し つつある。ヒ素は元来地殼中に存在する鈗物であ ることから、地下水中にヒ素が検出される事例は しばしば知られており、日本国内においても表流 水・地下水ともに基準值を超過することが最も多 い項目となっている(環境庁、1999)。

地下水七素污染の原因は、鉱工業の廃棄物にと もなう人工的なものと、鉱工業や農薬の影響をと もなわない自然的なものに区分できる(柴崎・吉 村、2000)。前者には日本の宮崎県土呂久・松尾 鉱山、新潟県中条町、タイ南部のロンピブン鉱山 などがあり、後者には南米、ハンガリー、中国、 ガンジスデルタ地域などがある(堀田、1997)。こ のうち、インド西ベンガル州とバングラデシュの ほぼ全域に相当するガンジスデル夕地域は、世界 で最も地下水七素污染の激しい地域であると言わ れている(Mandal et al., 1996)。

インド西ベンガル州での地下水ヒ素污染の発見 が1980年代であったのに対し、バングラデシュで の公式の確認は1993年 (Khan et al., 1997) と約10 年の差がある。この間インド西ベンガル州ではヒ 素中毒患者の確認や緊急対策用の代替水源確保が 進みつつあったが、バングラデシュでは未たに地
下水ヒ素污染の全貌が把握できていない。政府や 研究者、NGO 組織などの水質調査や医療調査が 行われるたびに、高濃度のヒ素污染地域やヒ素 中毒患者が新たに確認されるといった状況にあ るが、世界最貧国のひとつであるバングラデシュ では調査・対策の進みも遅い。インド西ベンガル 州のヒ素中毒患者は約20万人と見積もられている が(Mandal et al., 1996)、バングラデシュでの患 者数は政府機関も正確には把握していない。一 方、ヒ素に污染された井戸の分布範囲から想定し て、約 5,000 万人がヒ素污染の危機に曝されてい るとの指摘もあり (Dhar et al., 1997)、污染実態 の把握と緊急対策用水源の確保が求められてい る。

筆者ら応用地質研究会 (応地研) は、日本のNGO グループであるアジア砒素ネットワーク(AAN) とともに、バングラデシュや中国内蒙古などで の現地調査を共同で継続してきた。本編ではと くにバングラデシュでの活動について、この間 の経緯と現地調査で得られた結果を紹介するとと もに、日本の水文地質学の経験が国際協力に果た すべき役割について議論したい。なお、中国内蒙 古での活動の一部は、高・応用地質研究会内モン ゴル地下水調查班(1999)によって報告されてい る。 


\section{2. バングラデシュの地下水ヒ素污染の実態と地} 下水利用の歴史

\section{1 地下水ヒ素污染の実態}

バングラデシュはヒマラヤ山脈を源流とする大 河川(ガンジス川やブラマプトラ川など)の河口部 に位置し、国土の大半が標高 $20 \mathrm{~m}$ 以下の平坦な地 形を形作っている(図 1)。年間降水量のほとんど が 6 9月の雨季に集中しており、海岸部や河川 沿いを中心に毎年のように水害が発生する。河川 の氾濫とともに大量の土砂が供給され、バングラ デシュの地下には洪水氾濫性堆積物やデルタ堆積 物が厚く堆積している。これらの堆積物は砂層や 砂礫層を主体としており (Umitsu，1987)、きわめ て良好な帯水層を構成している。

ところが、この帯水層中の地下水に高濃度のヒ 素が含まれていることが、ここ数年の調査で明ら かになってきた(Khan et al., 1997；DCH，1998； DfID，1999）。地下水中の七素濃度は、高濃度の もので $1 \mathrm{mg} / \mathrm{L}$ を超えることがしばしば報告され ており(Dhar et al., 1997;DfID，1999)、WHOの

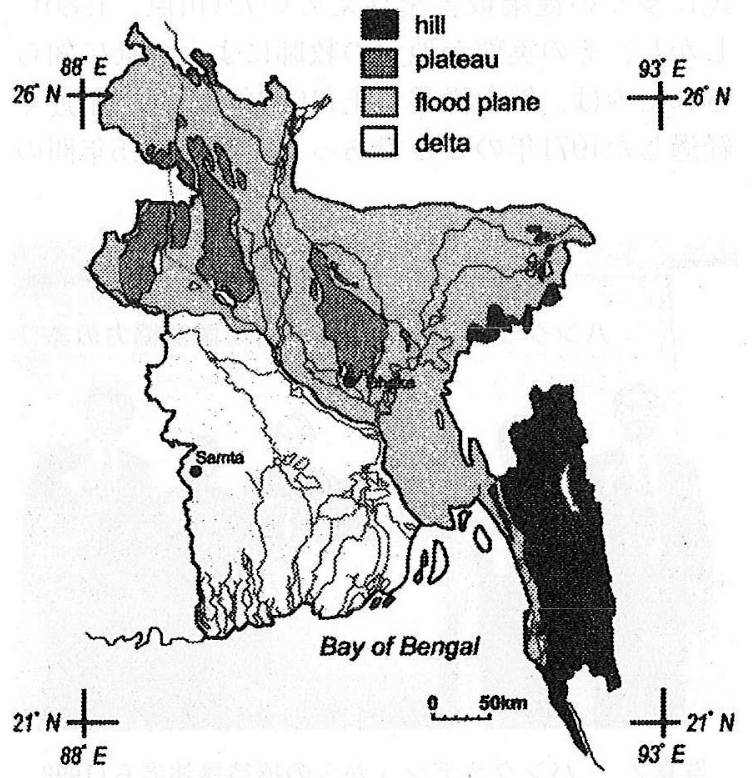

図 1 地形区分図(Islam，1996をもとに作成)

Fig. 1 Topographical map of Bangladesh. (Modified after Islam, 1996)
旧ガイドラインの $0.05 \mathrm{mg} / \mathrm{L}$ を越える地域は国土 の $2 / 3$ 以上に及んでいる(図 2 )。しかし、現時点 では污染機構解明にせまる科学的調査が始まった ばかりであり、地下水七素污染問題の解決には多 くの課題が残されている。

\section{2 地下水利用の歴史と現状}

バングラデシュでは、井戸が普及する以前は川 や池の水を飲用に利用していたことから、伝染病 による死者があとを絶たなかった。そのためユニ セフなどの機関が中心となり、約 20 年まえから飲 料用水の地下水への転換を奨励してきた。現在で は、都市部の水源井の設置や農村部の手押しポン プ井戸の普及によって、国民の $95 \%$ が飲料水を地 下水に依存するまでになっている。雑菌を含まな い安全な水源が得られたことと、川や池からの水 汲みの重労働から解放されたことは、住民の生活 習慣を大きく変化させた。バングラデシュ国内に 確実に定着してきた地下水利用は、住民の生活か ら切り離すことのできないものになっている。

また、1980年代後半に農業用井戸の利用が急速

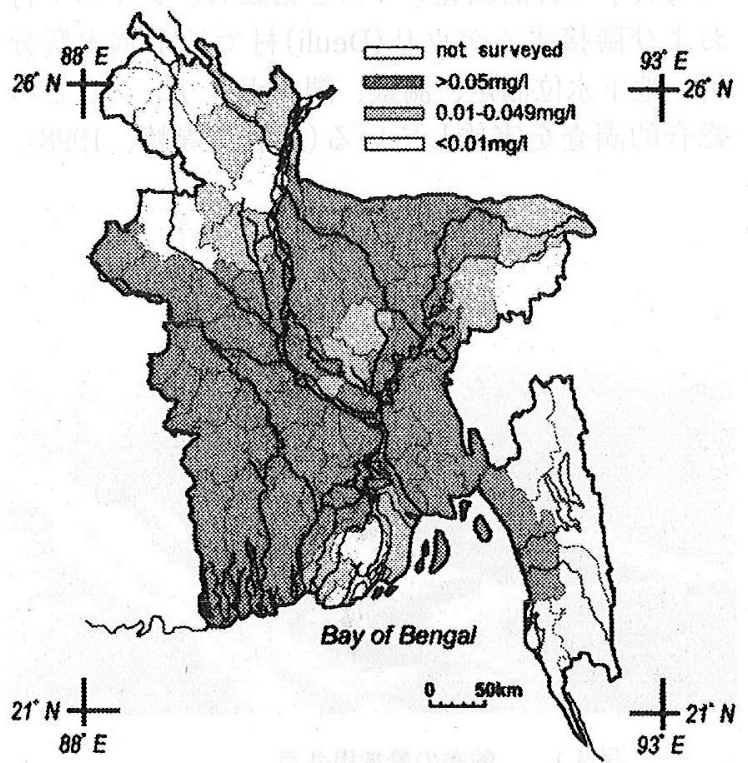

図 2 七案污染分布図(DCH and SOES，1997をも とに作成)

Fig. 2 Arsenic contamination in groundwater of Bangladesh. (Modified after DCH and SOES, 1997) 
に普及し、現在でも農業用水の需要は増大して いる(藤田、1993; Asia Arsenic Network et al., 1999)。バングラデシュでは乾季と雨季の降水量 の差がはっきりしており、乾季の水田耕作には、 かんがい用水としての地下水が必要不可欠のもの となっている(写真 1)。

\section{3. 研究活動の経緯}

\section{1. 応用地質研究会と AAN の活動}

応地研ではバングラデシュの地下水ヒ素污染機 構解明のために、AANと協力し1996年より現地調 査を継続してきた(応用地質研究会七素污染研究 グループ；1997）。1996年12月には応地研・AAN の合同予備調査によって污染地域の視察を行い、 バングラデシュ西部のシャム夕(Samta)村を重点 調査地域にすることを決めた(坂東・応用地質研 究会、1997)。1997年 3 月には、AAN と宮崎大学 の研究者らが中心となり、シャム夕村に分布する 全井戸 (282井戸) を対象とした地下水水質調査を実 施し、地下水七素污染の実態を明らかにした(横田 ほか；1997）。1997年10月からは、応地研・AAN · 宮崎大学の合同調査チームを結成し、シャム夕村 および隣接するデウリ(Deuli) 村で地下水水質分 析、地下水位測定、測量、調査ボーリングなどの 総合的調査を実施している(工藤・寺崎、1998)。

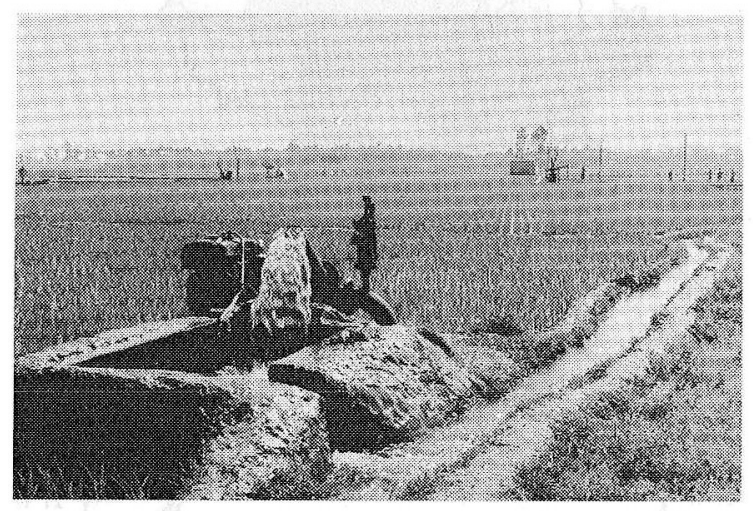

写真 1 乾季の晨業用井戸

Photo 1 Irrigation well in dry season.
さらに、村内に観測用井戸を設置し、シャム夕村 住民の協力によって地下水位が継続して測定され ている。また、AANは独自の医療調査、村落調 査を、シャム夕村を中心に実施している。

これらの現地調査と平行しながら、日本国内で は試料分析やデー夕解析を行い、その都度成果の 到達点を確認している。1996年に始まった「アジ ア地下水ヒ素污染フォーラム」は毎年実施され、 2000年の今年は 5 回目を計画している。1998年の フォーラムでは、バングラデシュから 5 人の研究 者や関係者を招待し、国際協力のあり方について も議論してきた(写真 2$) 。$

\section{2 土呂久から始まったヒ素污染問題への取り 組み}

AANがアジアのヒ素污染問題に取り組み始め たのは1992年にさかのぼるが、さらに20年以上も 前からヒ素中毒患者救済のための活動が続けられ ていた(川原、1988)。AANの母体となった組織 は、宮崎県土呂久鉱山の鉱害問題に苦しむ住民を 支援する会の人たちであった。土呂久鉱山では硫 砒鉄鉱を焼くことで車ヒ酸を大気中に放出し、住 民に多くの健康被害を与えていた(川原、1980)。 しかし、その実態が地元の教師によって世に知ら されたのは、鉱山操業停止(1962年)加 10年近く 経過した1971年のことであった。その後15年間の

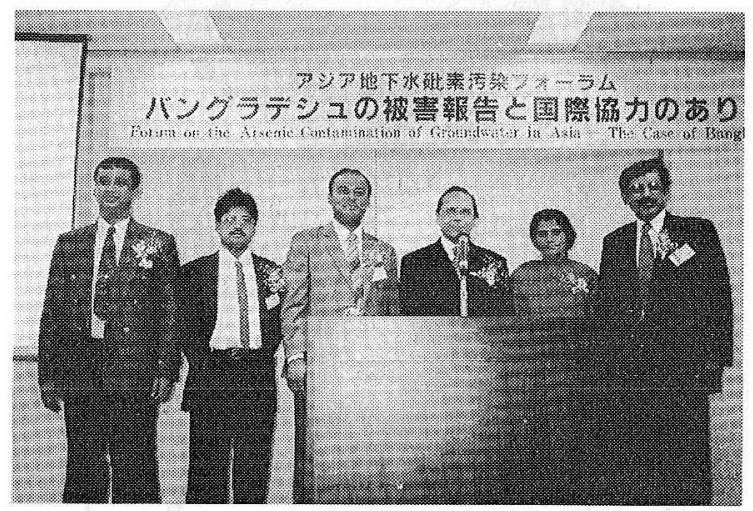

写真 2 バングラデシュからの招待講演者ら (1998 年11月)、右から三番目は在日バングラデ シュ大使

Photo 2 Invited guest from Bangladesh (Nov. 1998). The third person from right side was Ambassador of Bangladesh. 
裁判䦔争を経て、1990年には鉱山主との和解が成 立するに至った。そして現在、ヒ素中毒患者を支 援してきた経験を、今度はアジアの各地でヒ素污 染に苦しむ住民のために活かそうと AAN が結成 されたわけである(川原、1997)。

AAN は医療調查、社会調査、表流水調査など を中心に活動を実施しており、その取り組みは多 方面から高く評価され、2000年 3 月に朝日新聞社 主催の第 1 回朝日「明日への環境賞」を受賞した (朝日新聞、2000年 3 月 5 日記事)。現在、AAN はバングラデシュの首都ダッカ市に現地事務所を 開設し、現地に根付いた本格的な活動を展開して いる。

\section{3 学際的・国際的研究を目指した活動}

AAN が医療・社会調査などを中心に活動を進め る一方、応地研は多くの関係者と協力しながら、 団体研究方式による水文地質学的調查を継続して いる。応地研会員は民間企業や自治体の技術者が 中心となり構成されていることから、国内外のさ まざまな現場での経験を活かすことはできたが、 試料分析などの研究条件には決して恵まれてはい なかった。そこで以前から $\mathrm{AAN}$ と協力関係にあっ た宮崎大学研究グループとの合同調查隊を結成す ることで、より総合的な研究活動を実現すること が可能となった。また、活動を続けていく過程 で、地球化学や鉱物学の研究者も調査に加わり、 地下水七素污染機構の解明にむけた活動を展開し つつある(山崎ほか、2000; 新潟大学地下水七素 污染研究グループ、2000)。

こうした学際的な取り組みに加えて、海外での 活動において現地研究者や住民の協力が、大きな 力となっている。バングラデシュ国内での既存資 料の入手や種々の手続きなどには、現地の大学教 官や国立研究所職員などが手助けしてくれてい る。また、シャム夕村住民は、われわれの現地調 査の際に調査員として行動をともにし、日常的に は地下水位の継続的な観測などで研究活動の一躍 を担っている。

\section{4. シャム夕村の地下水七素污染と水文地質的背景}

応地研・AANを中心としたシャム夕村とデウ
リ村での調查・研究活動は現在も継続中である が、その中間段階の成果は、すでにAsia Arsenic Network et al. (1999)や応用地質研究会七素污染研 究グループ・宮崎大学地下水ヒ素污染研究グルー プ(2000)、山崎ほか (2000)、新潟大学地下水七素 污染研究グループ(2000)に詳しく報告されている ので、ここではその概要を紹介する。

\section{1 地下水七素污染状況と地下水利用形態}

シャム夕村の地下水ヒ素污染状況は、横田ほ か(1997)の現地でのヒ素簡易測定結果によると、 WHO の飲料水基準值である $0.01 \mathrm{mg} / \mathrm{L}$ 以上の井戸 が $96.5 \%$ 、バングラデシュの基準值である 0.05 $\mathrm{mg} / \mathrm{L}$ 以上の井戸が $91.8 \%$ にも及び、 $0.5 \mathrm{mg} / \mathrm{L}$ 以 上の井戸でさえも $15.6 \%$ という深刻な事態が確 認された。さらにヒ素濃度の平面分布を見ると、 村の南部に $0.5 \mathrm{mg} / \mathrm{L}$ を超える高濃度ヒ素を含む 井戸が分布しており、北東部ほどヒ素濃度が低い という明瞭な特徵が見られた（図 3 )。これらは民 家所有の井戸を主体としており、深度は20４0m である。

そのほかバングラデシュ政府のヒ素污染対策用 井戸(深度200 220m) が数本設置されているが、 低濃度であってもヒ素は検出され、高いもので は $0.05 \mathrm{mg} / \mathrm{L}$ 以上を示すこともある。また、集落 周辺の水田地帯には農業用井戸が設置されてお り、深度は $30 \mathrm{~m}$ 前後と $90 \mathrm{~m}$ 前後に分かれ、平均的 なヒ素濃度は民家井戸ほど高くはないが、高いも

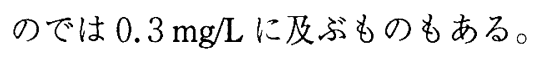

\section{2 地質と帯水層}

シャム夕村とその周辺地域はきわめて平坦な地 形を構成しているが、わずかの高度差から自然堤 防、後背湿地、汇濫原などに区分される。既存資 料と現地でのボーリング調査・検土杖調査などか ら、下位より下部砂質層、下部泥質層、上部砂質 層、上部泥質層、最上部砂質層、および最上部泥 質層の分布が確認された(図 4)。上部泥質層の層 厚は、シャム夕村北部で約 $10 \mathrm{~m}$ 、中央部から南側 で約 $6 \mathrm{~m}$ 、北東部で約 $1 \sim 2 \mathrm{~m}$ である。

これら各層は、下位より第二被圧带水層、第二 難透水層、第一被圧带水層、第一難透水層、およ び不圧帯水層に相当する。シャム夕村で最も地下 


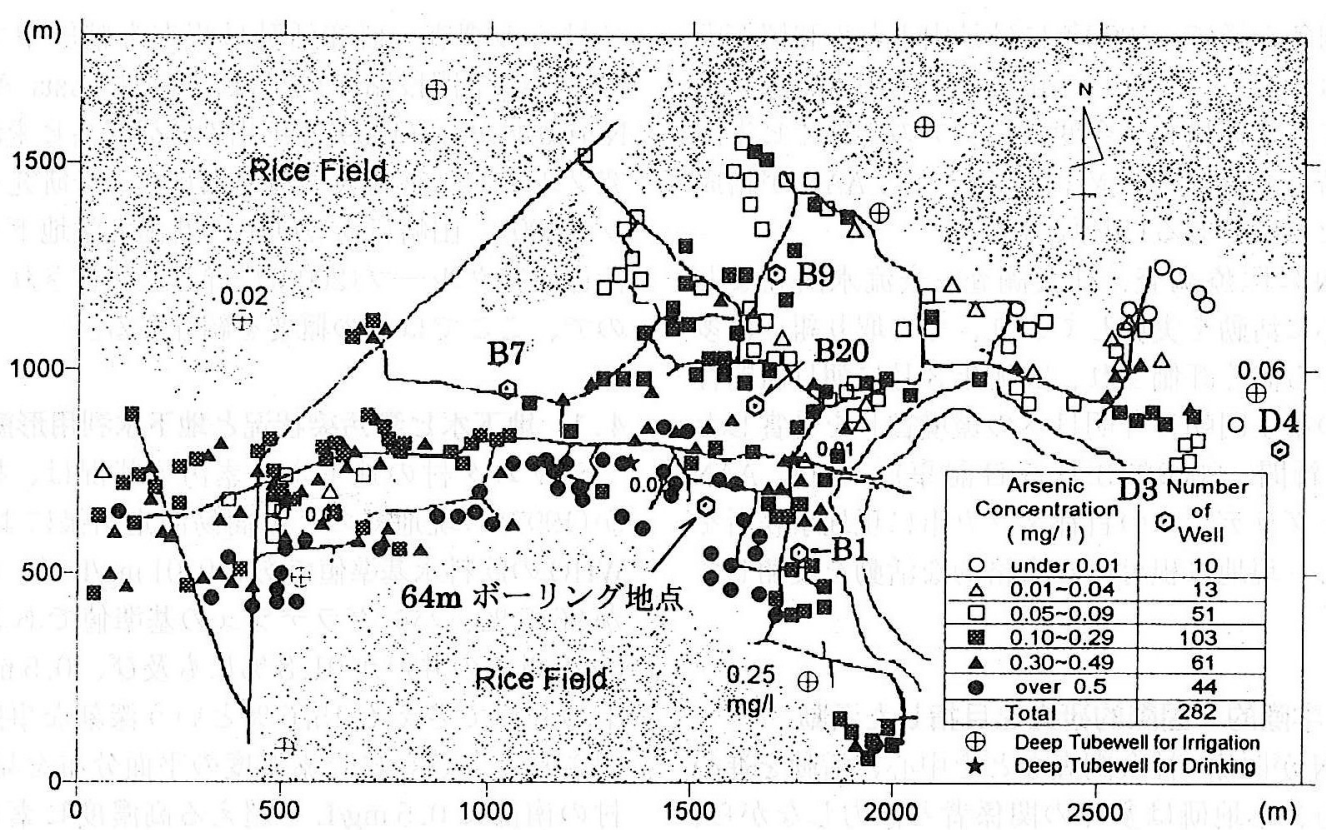

図 3 シャムタ村ヒ紊污染分布図(1997年 3 月) (Asia Arsenic Network et al, 1999)

Fig. 3 Arsenic contamination of groundwater in Samta (March, 1997). (Asia Arsenic Network et al, 1999 に一部加筆)

\begin{tabular}{|c|c|c|c|c|c|}
\hline Layer & & Lithological facies & Aquifer unit & $\begin{array}{l}\text { Distribution } \\
\text { depeh(m) }\end{array}$ & Thickness(m) \\
\hline Embankment(b) & & silt and clay & & $0 \sim 1.5$ & $0 \sim 1.5$ \\
\hline $\begin{array}{l}\text { Uppermost } \\
\text { muddy layer } \\
\text { (umm) }\end{array}$ & & silt and clay & & $0 \sim 4$ & $0 \sim 3$ \\
\hline $\begin{array}{l}\text { Uppermost } \\
\text { sandy layer } \\
\text { (ums) }\end{array}$ & & very fine sand & Unconfined aquifer & $1 \sim 6$ & $0 \sim 3$ \\
\hline $\begin{array}{l}\text { Upper } \\
\text { muddy layer } \\
\text { (um) }\end{array}$ & & $\begin{array}{l}\text { silt and clay } \\
\text { with organic materials }\end{array}$ & First aquitard & $1 \sim 15$ & $0.8 \sim 12$ \\
\hline $\begin{array}{l}\text { Upper } \\
\text { sandy layer } \\
\text { (us) }\end{array}$ & कn & fine to medium sand & First confined aquifer & $10 \sim 110$ & $80 \sim 120$ \\
\hline $\begin{array}{l}\text { Lower } \\
\text { muddy layer } \\
\text { (lm) }\end{array}$ & $=$ & sandy silt to very fine sand & Second aquitard & $90 \sim 170$ & $0 \sim 60$ \\
\hline $\begin{array}{l}\text { Lower } \\
\text { sandy layer } \\
\text { (Is) }\end{array}$ & 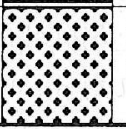 & $\begin{array}{l}\text { fine to coarse sand } \\
\text { with silt and granule layer }\end{array}$ & Second confined aquifer & $90+$ & $130+$ \\
\hline
\end{tabular}

図 4 シャムタ村の地質層序と带水層区分(応用地質研究会ヒ素污染研究グループ・宮崎大学地下水七素污染研 究グループ、2000)

Fig. 4 Stratigraphy and aquifer unit classification. (Research Group for Applied Geology, Sub-group for Arsenic Contamination and Miyazaki University Research Group for Arsenic Contamination in Groundwater, 2000) 
水利用の多い、上部砂質層(第一被圧帯水層)の層 相は、泥質層が一部挟在し細粒砂からなる上部 と、中一粗粒砂を主体とする下部にさらに区分さ れる。前述の地下水利用状況を対応させると、第 一被圧帯水層上部は民家井戸と農業用井戸、第一 被圧帯水層は農業用井戸、第二被圧帯水層は政府 のヒ素污染対策用井戸が取水対象としている。第 一被圧带水層加第二被圧带水層にかけては、浅 層から深層に向かって地下水中ヒ素濃度が高くな る傾向が顕著に現れている(図 5 )。

\section{3 地層中の七素含有量}

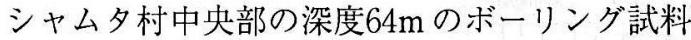
とシャム夕村およびデウリ村での深度約 $15 \mathrm{~m} の$ ボーリング試料についてヒ素含有量の分析を行っ たところ、すべての地点において上部泥質層のヒ 素含有量が高く、上部砂質層は比較的低い值を示 した(図 6、図 7)。さらに上部泥質層の中でも、 とくに有機質堆積物中の七素含有量が高いという 特徴が認められた。また、ヒ素と鉄の含有量に は、上部泥質層、上部砂質層ともに、良い相関が 認められる。

前述の地下水中七素濃度が浅層の帯水層ほど高 いという特徵を考えると、上部泥質層中に含有さ れるヒ素が地下水中に溶出することで、地下水七 素污染が発生していると想定される。一方、上部

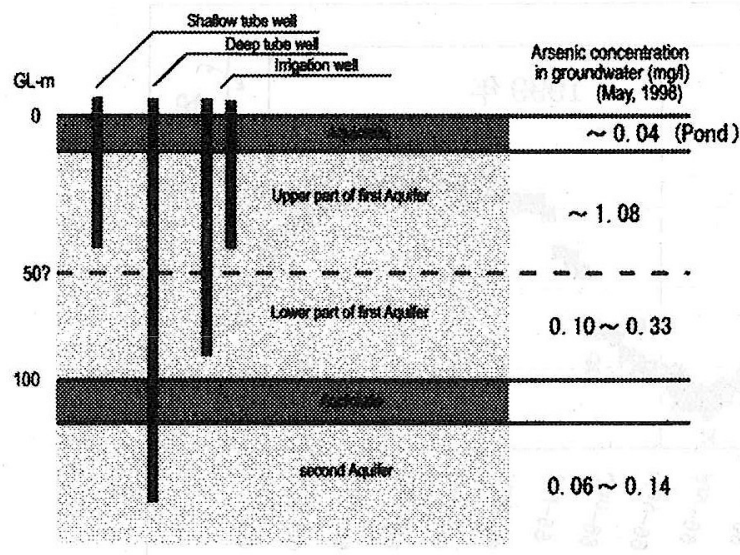

図 5 シャム夕村の带水層とヒ紊濃度分布概念図 (Asia Arsenic Network et al., 1999)

Fig. 5 Schema of arsenic concentration in Samta. (Asia Arsenic Network et al., 1999)

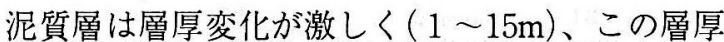
の違いが地下水中ヒ素濃度の地域性に影響してい る可能性も考えられ、泥質層堆積時の古環境復元 が重要な鍵を握っている。

\section{4 地下水位変動特性}

筆者らはシャム夕村とデウリ村に27本の地下水 位観測井を設置し、現在シャム夕村住民の協力に よって18本の観測が継続されている。最も観測期 間の長いものでは、1998年 5 月以降の観測值が得 られている(図 8)。

地下水位は地表面下約 $2 \sim 8 \mathrm{~m}$ の範囲で変動し ており、1年の周期的変動が顕著に現れている。 変動の特性は、1 4 月の水位低下期、 $5 \sim 7$ 月 の水位上昇期、 $8 \sim 12$ 月の高水位期に大まかに区 分できる。バングラデシュの気象条件は、 6 ～9
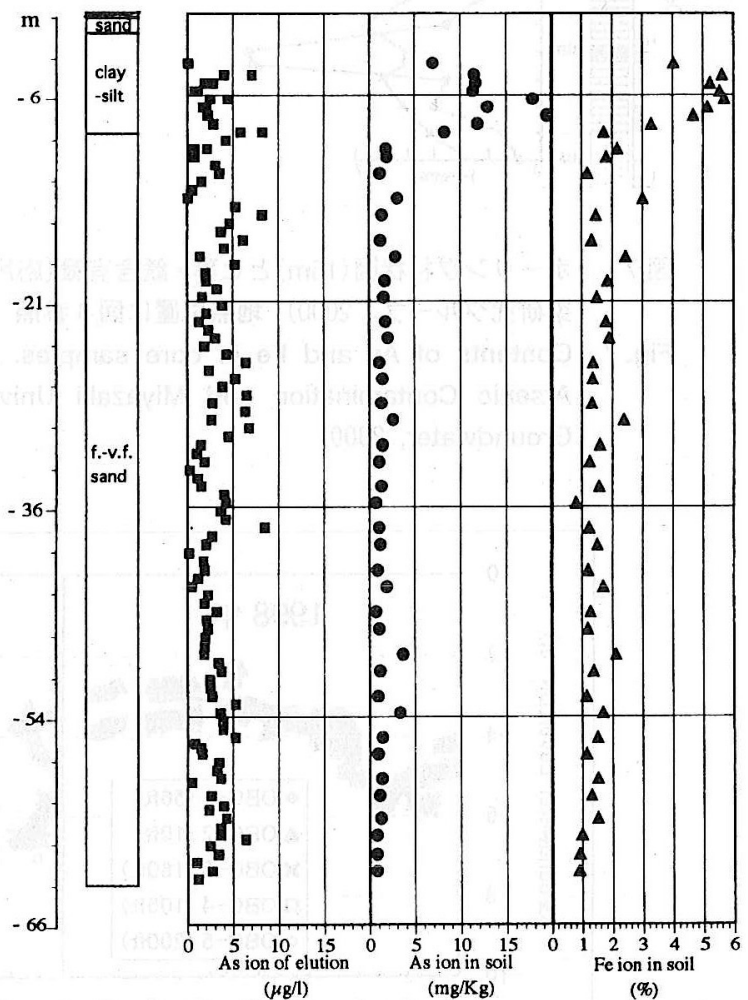

図 6

ボーリシグ柱状図 $(64 \mathrm{~m})$ とヒ亲含有量・溶出量 および鉄含有量(Asia Arsenic Network et al., 1999)：地点位置は図 3 参照

Fig. 6 As content, elution and Fe content of boring core samples in Samta. (Asia Arsenic Network et al.,1999) 

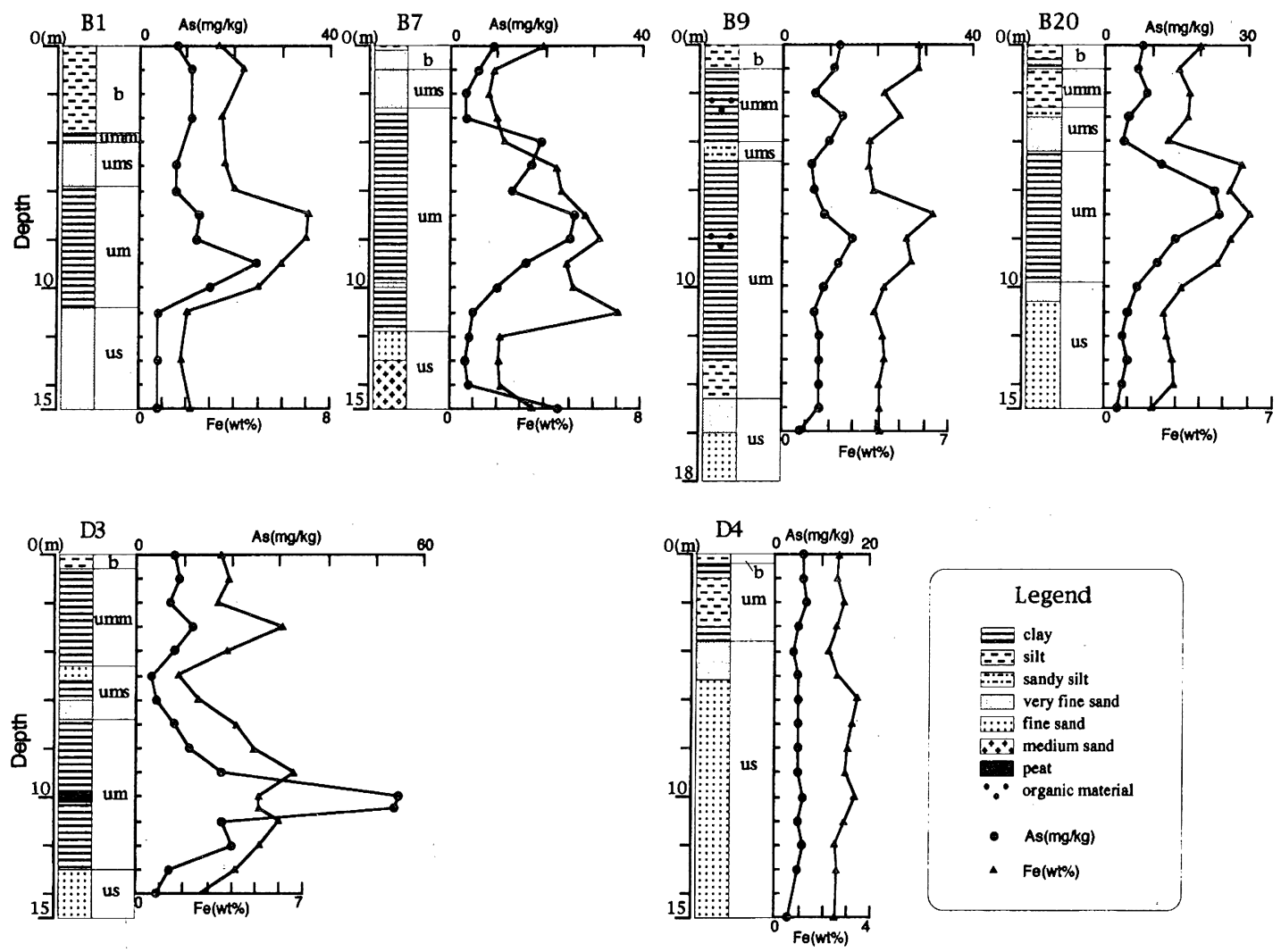

図 7 ボーリング柱状図 $(15 \mathrm{~m})$ とヒ亲・鉄含有量(応用地質研究会ヒ秦污染研究グループ・宮崎大学地下水ヒ亲污 染研究グループ、2000)：地点位置は図 3 参照

Fig. 7 Contents of As and Fe in core samples. (Research Group for Applied Geology, Sub-group for Arsenic Contamination and Miyazaki University Research Group for Arsenic Contamination in Groundwater, 2000)

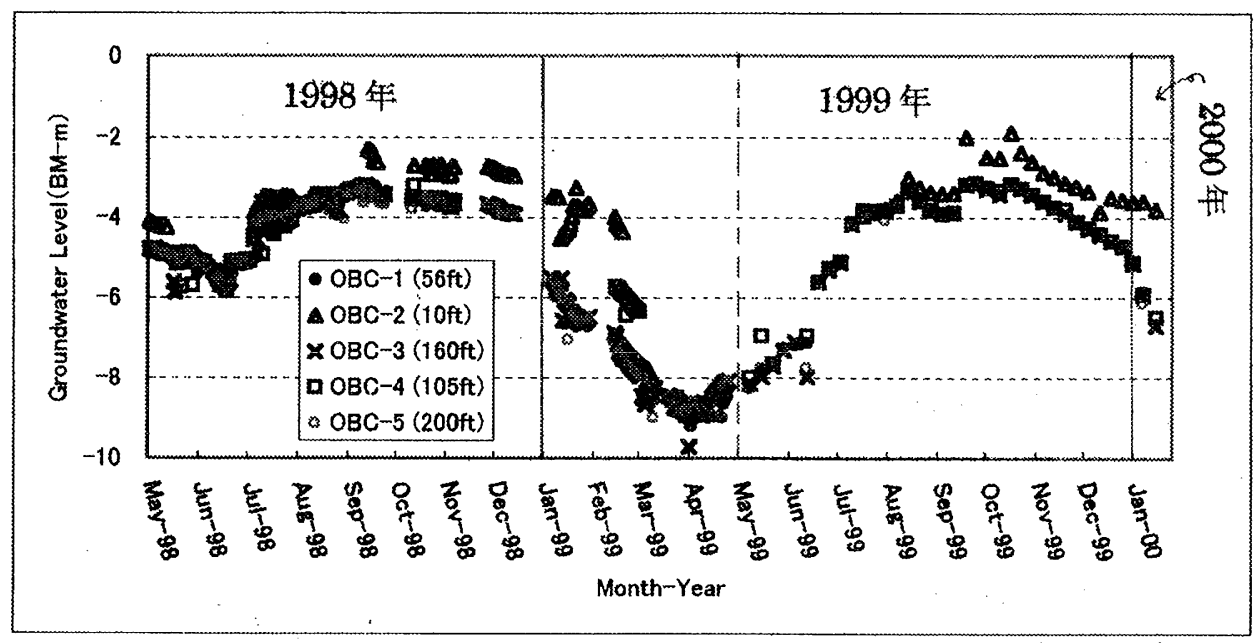

图 8 シャムタ村中央部の観測井における地下水位変動

Fig. 8 Changes in groundwater level measured at observation well in the central Samta. 
月が雨季の中心であり、シャム夕村の地下水位変 動特性にも強く反映されている。しかし、1〜4 月の急激な地下水位の低下は、ほほ同時期に集中 する農業用地下水の揚水に起因しているものと判 断される。

\section{5 シャムタ調査の到達点と課題}

ヒ素の地下水中での挙動には酸化還元条件の変 化が重要な要素となっており(島田、1998)、バン グラデシュの地下水ヒ素污染機構についてもさま ざまな方向からの議論が起こっている。Das $e t$ al. (1996) はインド西ベンガル州での調査経験か ら酸化環境下でのヒ素溶出を指摘しているが、バ ングラデシュでの最近の研究では還元環境下での 溶出を示唆する研究が見られる (Nickson et al. , 1999 ; 山崎ほか、2000 ; 新潟大学地下水七素污染 研究グループ、2000)。

ヒ素の溶出機構についてはまだ多くの課題が残 されているが、シャム夕村の調査では以下の点が 明らかになうた。

（1）シャム夕村では第一被圧帯水層(上部砂質層) と第二被圧帯水層(下部砂質層)が主帯水層に なっており、とくに第一被圧带水層上部(深 度約10 50m)の地下水中七素濃度が高い。

（2）第一被圧帯水層上部の地下水中七素濃度は シャム夕村北東部から南部にかけて高濃度化 し、最も高いものでは $1 \mathrm{mg} / \mathrm{L}$ を超える。

（3）シャム夕村およびデウリ村の地層中ヒ素含有 量は上部泥質層中で高く、とくに有機質堆積 物中で高い。

（4）第一被圧帯水層の年間地下水位変動特性には 雨季と乾季の周期性を確認できるが、乾季の 農業用井戸稼動時期の水位低下はより顕著で あり、降水量の影響に加えて人為的影響の強 いことが読み取れる。

以上のことを総合的に検討すると、主として農 業用地下水の過剩揚水が、漏水や絞り出し現象を 伴うような垂直方向の地下水流動を生じさせ、本 来の地下水循環系のバランスを崩していることが 考えられる。そのことで、地下の酸化還元条件の 変化が促進され、ヒ素污染の進行を加速させてい る可能性がある。また、農業増産に伴う肥料使用 量の増大や、人口増加に伴うし尿の無秩序な拡散
などが、地下での環境変化を引き起こし、地質的 な污染の進行を(ヒ素污染も含めて)招いている可 能性も指摘されている(山崎ほか、2000)。今後 は、より詳細かつ多角的な調査によって地下水七 素污染機構を解明するとともに、地下水利用の管 理体制を国家的規模で確立する必要がある。

\section{5. 住民に安全な水を供給するために}

\section{1 応地研の今後の活動}

応地研の活動はすでに述べたとおり、AAN・宮 崎大学グループと協力しながら、シャム夕村の現 地調査を中心に実施してきた。さらに、毎年ヒ素 污染フォーラムを企画することで議論を深めなが ら調査結果の解析を進め、中間段階での成果を公 表してきた(Asia Arsenic Network et al., 1999; 応用地質研究会ヒ素污染研究グループ・宮崎大学 地下水ヒ素污染研究グループ、2000)。

そのような応地研の活動上の資金は、トヨ夕財 団、イオングループ環境財団、全労済の研究助成 を得ることで確保してきた。しかし、研究助成か ら支出できない調査参加者の渡航費、滞在費など は、原則として個人負担によるボランティア精神 で維持してきた。また、メンバーの大半が日常業 務の合間をぬっての参加形態であったことから、 現地調査は年末や 4 ～月にかけての休暇時期に しか設定することができず、おのずと活動計画に も制限を加えざるを得なかった。とくに 4 〜月 はバングラデシュの年間で最も暑い時期に相当 し、日中気温が $40^{\circ} \mathrm{C}$ 超える過酷な条件での現地 調査であった。

それでも活動を継続して来られたのは、AANや 現地の研究者らのヒ素污染問題解決に向けた情熱 がわれわれにも伝わってきたからだと考えてい る。宮崎大学の研究者や途中から調査に加わって くれた大学関係の研究者からは、応地研メンバー だけでは対応できない各種分析・計測作業を引き 受けてもらえた。

バングラデシュでの地下水ヒ素污染問題が表面 化したとき、先進国や国際援助機関は現状把握に 終始し、具体的な対応が取れぬまま時間が経過 していた。AAN や応地研が NGO という組織形態 だったからこそ、現場の問題に機敏に対応できた 
ものと考えている。現在、多くの先進国や援助機 関が本格的な調査に乗り出しつつあり、その背景 には AAN や応地研の活動が多少なりとも刺激剤 になったのではないかと自負している。先に述べ たとおり、資金的・研究条件的制約から大規模な 調査は応地研の活動範囲を超えてしまうこともあ るが、それらについてはバングラデシュ政府や国 際機関の活動に期待しつつ、応地研としても積極 的な提言を行って行きたい。応地研は今後も NGO 組織だからこそできる、地に足の着いた活動を現 地研究者や住民らとともに進めていきたいと思っ ている。

\subsection{AAN の今後の活動}

応地研が宮崎大学グループと共同で水文地質調 查を実施する一方、AAN はヒ素中毒患者の医療 診断調查、村の経済社会調査、雨水利用調査など を進めてきた。また、AANと宮崎大学グループが 協力して、PSF(池水浄化装置)を建設した。PSF は、池の水を礫の間を通しながら緩速ろ過によっ て鿇化するシステム装置で、この PSF 建設が、地 下水以外の代替水源として注目されているととも に、運営主体を住民に求めるものであり、村の自 治体制確立への可能性を秘めている。

これらの活動は今後も必要に応じて実施されて いくであろうが、さらに現在 AAN は新たな計画 を準備中である。それは、シャム夕での経験をよ り広い地域に活かしていくことであり、具体的構 想として「移動式砒素センター」が計画されてい る。移動式砒素センターは、医師、技術者などが 必要な機材・薬品等を搭載した車両に乗ってヒ素 污染地を巡回し、被害実態把握、代替水・治療指 導、被害予防啓発などを行うものである。この活 動は、地元 NGO との連携や住民参加を原則とし て考えており、草の根レベルでの新たな発想に関 係各機関から大きな期待が寄せられている。

この移動式砒素センターは、まさに現地に根を 下ろした活動でなければ、実現することはできな い。そのため AAN は、2000年春から首都ダッカ に現地事務所を開設し、日本人とバングラデシュ 人の専属スタッフの常駐体制を作り上げた。この ような被害住民の救済を目指した献身的な NGO の活動に対して、われわれ学会に所属する研究
者・技術者はともに問題解決を目指すとともに、 それぞれの立場での可能な支援を行っていくべき だと考える。

\section{3 活動の中から生まれた国際協力の絆}

バングラデシュは自然条件の厳しさと歴史的め ぐり合わせから最貧国の現状を抜け出すことがで きず、援助が無くては国家の存在そのものが危ぶ まれる現状にある。そして、そのことが、この国 の援助依存体質を作ってしまっているとも言われ ている。政府高官の污職体質は消えることなく、 援助は唄富の格差を助長するだけであるとの指摘 もされている(ブリギッテ・エルラー、1987)。

しかし、筆者らが現地での活動を続けていく中 で、その活動に真摰な立場で協力してくれる研究 者に出会うことができたことは、われわれにとっ ては幸運であった。Rajshahi 大学地質鉱山学部の 教授らは、活動開始当初現地に不慣れな筆者らを 案内して、污染地域の概査や既存資料の収集など に奔走してくれた。NIPSOM(国立予防社会医学 研究所)の医師らは、現地調査時に地元住民と日 本人メンバーの間をつないでくれ、調査期間中の あらゆることに気配りしてくれた。

さらに特筆すべきことは、自らがヒ素污染の被 害を受けている筫しい村の住民たちが、独自にヒ 素対策委員会を結成し、われわれの現地調查活動 を受け入れてくれたことである(写真 3 )。先に述

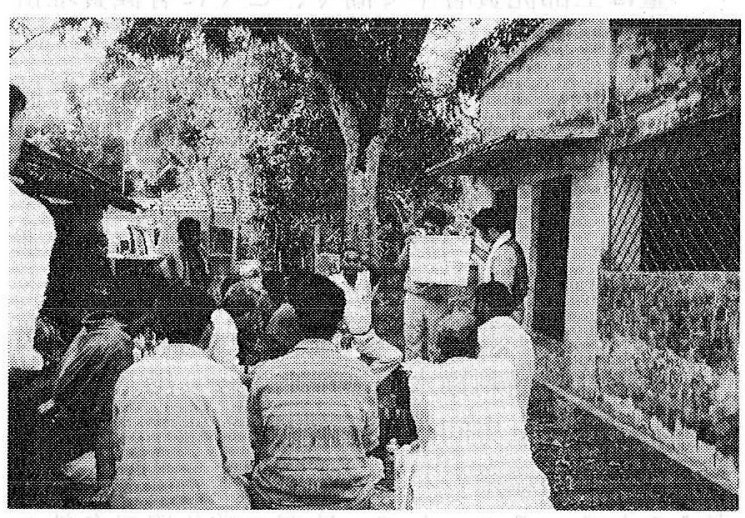

写真 3 住民を含めた調查内容の打合せ(工藤・寺 崎、1998)

Photo 3 Discussion of field survey with villager. (Kudo and Terasaki, 1998) 
ベたとおり、現地調査では住民が積極的に協力し てくれ、地下水位の観測はシャム夕村ヒ素対策委 員会のメンバーが交代で実施してくれている。そ の中心が、村の将来を背負って立つ青年らである ことには、混沌としたバングラデシュの社会構造 の中にもわずかな希望を見出すことができる。こ の住民自立化の動きも、応地研が現地に入る以前 から、AANが住民とのふれあいを大切にしなが ら活動を続けてきたことの成果である。

\section{4 住民のための科学を}

現在バングラデシュでは、大半の住民が貧困生 活の中で自らの命をつなぎ止めようと、日々の生 活にあえいでいる。バングラデシュの豊富な水資 源は、すべての住民に与えられていた唯一の宝で あったはずが、今はその命さえも奪おうとしてい る。

先進国の恵まれた条件の中で学問・研究を進め ることのできる、われわれ研究者・技術者が、お 互いの専門分野を超えて協力し合うことが、今ま さに求められている。とくに日本の研究者・技術 者は、高度経済成長から現在にかけて激しい公 害・環境問題に直面してきた。地下水分野に限っ て言えば、地下水盆管理の概念を導入した地盤沈 下問題の克服や、水文地質学の基本を徹底的に実 践してきた地下水污染問題への技術開発などは、 この地下水ヒ素污染問題への重要な経験になると 思われる。

世界に普遍的に起こりうるこの広域地下水污染 問題に対して、ぜひ日本国内でも、専門分野の枠 を超えた議論が、積極的に展開されることを期待 する。

\section{参考文献}

応用地質研究会ヒ素污染研究グループ(1997)：地下水 七素污染問題への今後の取り組み. 地学教育と科学 運動特別号、アジア地下水ビ素污染問題を考える、 116 119 .

応用地資質研究会ヒ素污染研究グループ・宮崎大学地

下水七素污染研究グループ(2000): バングラデシュ 西部シャム夕村における地下水七素污染と水文地質 的背景. 地球科学、54(2)、105 126.
川原一之(1980)：『口伝亜砒焼き谷』岩波新書、（黄版） 137、242p.

川原一之(1988)：『埩土むら土呂久一文明といのちの史 記』築摩書房、236p.

川原一之(1997)：土呂久からアジア砒素ネットワーク へ. 地学教育と科学運動特別号、アジア地下水ヒ素 污染問題を考える、2 5.

環境庁 (1999):『平成11年版環境白書総説』環境庁編、 $486 \mathrm{pp}$.

工藤周一・寺崎紘一(1998) : バングラデシュ地下水七素 污染問題の解明をめざしてーシャム夕村ヒ素污染調 查報告一. 地学教育と科学運動、30、25 34.

高 存栄・応用地質研究会内モンゴル地下水調査班 (1999): 内モンゴル河套平野における地下水ヒ素污 染. 地球科学、53(6)、434 451.

柴崎達雄・吉村尚久 (2000): アジア地下水七素污染調査 一 NGO の救援活動と専門家集団の役割. 日本の科学 者、35(3)、32 -36.

島田允蕘 (1998): 砒素含有地下水の地質環境一福岡県 南地域を例にして一. 砒素をめぐる環境問題、地質 環境と地球環境シリーズ 4、東海大学出版会、95 116.

新潟大学地下水七素污染研究グループ(2000): 地下水 ヒ素污染の起源物質を含むバングラデシュ、シャム 夕村ボーリング試料の構成鉱物とその特徵. 地球科 学、54(2)、94 104 .

坂東和郎・応用地質研究会 (1997): バングラデシュにお けると素含有地下水予備調查. 地学教育と科学運動 特別号、アジア地下水ヒ素污染問題を考える、88 94.

藤田幸一(1993): バングラデシュ農業発展論序説一技 術選択に及ぼす農業構造の影響を中心に。農業経済 研究所. 30-37、56-57、66-69.

ブリギッテ・エルラー〔伊藤明子訳〕 (1987)：『死を招く 援助一バングラデシュ開発援助紀行』亜紀書房、 $237 \mathrm{p}$.

堀田宣之 (1997): 地下水七素污染地域の地理学的状況. 地学教育と科学運動特別号、アジア地下水ヒ素污染 問題を考える、14〜27.

山崎静子·石賀裕明 · 道前香緒里 - 東 直子·F. Ahmed 三瓶良和・M.H. Rahman・M.B. Islam(2000)：バング ラデシュ、ガンジスデルタ堆積物の元素組成一七素 はピートから溶出する? 一. 地球科学、54(2)、81 
93.

横田 漠 - 田辺公子 - 秋吉康弘 - 川原一之 - 橋口三夫 · 対馬幸枝·A.W. Khan, S.A. Ahmad, S.A. Hadi(1997)： ガンジスデル夕最大の地下水七素污染一シャム夕村 における調査結果一. 地学教育と科学運動特別号、 アジア地下水七素污染問題を考える、95 104.

Asia Arsenic Network, Research Group for Applied Geology and DOEH, National Institute of Preventive \& Social Medicine (1999): Arsenic Contamination of Groundwater in Bangladesh. Interim Report of the Research at Samta Village, 90p.

Das D., G. Samanta, B.K. Mandal, T.R. Chowdhury, C.R. Chanda, P.P. Chowdhury, G.K. Basu and D. Chakraborti (1996): Arsenic in groundwater in six district of West Bengal, India. Environ. Geochem. Health, 18(1), 5 15.

DCH and SOES (Dhaka Community Hospital Trust and School of Environmental Studies, Jadavpur University) (1997) Groundwater Arsenic Contamination in Bangladesh. In Arsenic Pollution in Groundwater of Bangladesh, Dhaka Community Hospital Trust, $14 \mathrm{p}$.

DCH (Dhaka Community Hospital Trust) (1998): The arsenic problem in Bangladesh -An introduction to the country and its arsenic situation. In: Proceedings of International Conference on Arsenic Pollution of Ground Water in Bangladesh, Causes, Effects and Remedies, $27 \sim 30$.

DfID (Department for International Development, United Kingdom) (1999): Groundwater Studies for arsenic contamination in Bangladesh. Phase I: Rapid Investigation Phase, Final Report prepared for
DPHE by British Geological Survey and Mott MacDonald Ltd.

Dhar K.R., B.K. Biswas, G. Samanta, B.K. Mandal, D. Chakraborti, S. Roy, A. Jafar, A. Islam, G. Ara, S. Kbir, A.W. Khan, S.A. Ahmed and S.A. Hadi (1997): Groundwater arsenic calamity in Bangladesh. Current Science, 73(1), 48 59 .

Islam A.M. (1996) Graphosman World Atlas. Graphosman, Bangladesh, 56p.

Khan A.W., S.A. Ahmad, M.H.S.U. Sayed, S.A. Hadi, M.H. Khan, M.A. Jalil, R. Ahmed and M.H. Faruquee (1997): Arsenic contamination in ground water and its effect on human health with particular reference to Bangladesh. Journal of Preventive \& Social Medicine, 16, 65 73.

Mandal B.K., T.R. Chowdhury, G. Samanta, G.K. Basu, P.P. Chowdhury, C.R. Chanda, D. Lodth, N.K. Karan, R.K. Dhara, D.K. Tamili, D. Das, K.C. Saha and D. Chakraborty (1996): Arsenic in groundwater in seven districts of West Bengal, India - The biggest arsenic calamity in the world. Current Science, 70(11), 976 986.

Nickson R.T., J.M. McArthur, P. Ravenscroft, W.G. Burgess, K.M. Ahmed (1999): Mechanism of arsenic release to groundwater, Bangladesh and West Bengal. Applied Geochemistry, 15(4), 1 10.

Umitsu M. (1987) Late Quaternary Sedimentary Environment and Landform Evolution in the Bengal Lowland. Geographical Review of Japan (Ser B), 60, 164 $\sim 178$.

（受付：2000年 5 月 9 日、受理：2000年10月14日） 